\title{
TINJAUAN SEJARAH PENDIDIKAN ISLAM MASA ORDE LAMA
}

\author{
Oleh: \\ Muh. Aidil Sudarmono \\ Program Doktor UIN Alauddin Makassar \\ sudarmono.aidil@yahoo.com
}

\begin{abstract}
Abstrak:
Setelah Indonesia merdeka terutama pada zaman orde lama, pendidikan Islam sudah mulai berkembang. Hal tersebut, dibuktikan bahwa pemerintah khususnya pada masa orde lama (ORLA) sangat memperhatian pendidikan khususnya dalam pendidikan Islam. Dengan berbagai usaha yang dilakukan pemerintah sehingga pendidikan Islam mulai berkembang yang dibarengi dengan perumusan kebijakan-kebijakan strategis seperti bentuk pengelolaan pendidikan agama yang diberikan di sekolahsekolah umum tersebut maka pada bulan Desember 1946 dikeluarkan surat keputusan bersama (SKB) antara menteri pendidikan dan menteri agama yang mengatur pelaksanaan pendidikan agama pada sekolah-sekolah umum (negeri dan swasta) yang berada di bawah kementerian pendidikan. Disatu pihak kementerian agama juga mengelola semua jenis pendidikan agama baik di sekolah-sekolah agama maupun di sekolah-sekolah umum. Sementara itu, dilain pihak departemen pendidikan pengajaran dan kebudayaan mengelola pendidikan pada umumnya dan mendapatkan kepercayaan untuk melaksanakan system pendidikan nasional.
\end{abstract}

Kata Kunci: Sejarah, Pendidikan Islam, Orde Lama.

\section{Pendahuluan}

Berbicara tentang pendidikan Islam di Indonesia, sangatlah erat hubungannya dengan kedatangan Islam itu sendiri ke Indonesia. Pendidikan Islam di Indonesia seperti juga dibagian dunia Islam lainnya berjalan menurut rentak gerakan Islam pada umumnya dalam politik ekonomi, sosial, budaya, dan pendidikan. Pada permulaan abad ke-20 terjadi beberapa perubahan dalam Islam di Indonesia yang di dalam garis besarnya dapat digambarkan sebagai kebangkitan, pembaharuan, bahkan pencerahan atau renaisance. Perubahan yang berlaku dalam pendidikan Islam semenjak saat itu hanya dapat dipahami kalau kita melihat keterikatan antara berbagai aspek pembaharuan baik itu politik, 
ekonomi, sosial, maupun budaya. ${ }^{1}$ Eksistensi pendidikan Islam di Indonesia adalah suatu kenyataan yang sudah berlangsung sangat panjang dan sudah memasyarakat. Pada masa penjajahan Belanda dan penduduk jepang, pendidikan diselenggarakan oleh masyarakat sendiri dengan mendirikan pesantren, sekolah, dan tempat-tempat latihan lainnya. Setelah merdeka, pendidikan Islam dengan ciri khasnya madrasah dan pesantren mulai mendapatkan perhatian dan pembinaan dari pemerintah Republik Indonesia.

Menurut Mahmud Yunus bahwa sejarah pendidikan di Indonesia sama tuanya dengan masuknya Islam di Indonesia. ${ }^{2}$ Hal ini disebabkan karena pemeluk agama baru tersebut sudah barang tentu ingin mempelajari dan mengetahui lebih mendalam tentang ajaran-ajaran Islam. Ingin pandai sholat, berdo'a, dan membaca Al-qur'an yang menyebabkan timbulnya proses belajar meskipun dalam pengertian yang amat sederhana. Dari sinilah mulai timbul pendidikan Islam dimana pada mulanya mereka belajar di rumah-rumah, mesjid, dan kemudian menjadi pondok pesantren. Berangkat dari gambaran umum di atas tentang kedatangan Islam di Indonesia menjadi sangat penting untuk dikaji terutama yang berkaiatan dengan kedudukan pendidikan Islam dalam konteks sejarah pendidilkan nasional khususnya pada masa pemerinyahan orde lama (ORLA). Hal ini penting untuk diureakan dan di analisis, guna memahama langkah reforamtif pengembangan pendidikan Indonesi pada masa awal kemerdekaan Indonesia.

\section{Pembahasan}

\section{Pengembangan Pendidikan Islam Masa ORLA}

Setelah Indonesia merdeka penyelenggaraan pendidikan agama Islam mendapat perhatian serius dari pemerintah, baik di sekolah negeri maupun swasta. Usaha untuk itu dimulai dengan memberikan bantuan terhadap lembaga tersebut sebagaimana yang dianjurkan oleh Badan Pekerja Komite Nasional Pusat (BPKNP) tanggal 27 desember 1945 yang menyebutkan bahwa:

"Madrasah dan pesantren pada hakikatnya adalah satu alat dan sumber pendidikan dan pencerdasan rakyat jelata yang sudah

${ }^{1}$ Hasan Langgulung, Pendidikan Islam dalam Abad Ke 21, (Jakarta: PT. AlHusna Zikra, 2001), 58.

${ }^{2}$ Mahmud Yunus, Sejarah Pendidikan Islam di Indonesia, (Jakarta: Hidakarya Agung, 1985), 6. 
berurat berakar dalam masyarakat Indonesia umumnya, hendaklah pula mendapat perhatian dan bantuan nyata berupa tuntunan dan bantuan material dari pemerintah. ${ }^{3}$

Kenyataan yang demikian timbul karena umat Islam yang dalam, setelah sekian lama mereka terpuruk di bawah kekuasaan penjajah. Sebab pada zaman penjajahan Belanda pintu masuk pendidikan modern bagi umat Islam terbuka secara sangat sempit. Dalam hal ini minimal ada dua penyebab uatamanya, yaitu:

1. Sikap dan kebijaksanaan pemerintah colonial yang amat diskriminatif terhadap kaum muslimin.

2. Politik nonkoperatif para ulata terhadap Belanda yang menfatwakan bahwa ikut sertadalam budaya Belanda, termasuk pendidikan modernnya adalah satu bentuk penyelewengan agama. Mereka berpegang pada salah satu hadis Nabi Muhammad Saw yang artinya "barang siapa yang menyerupai satu golongan maka ia termasuk pada golongan itu". Hadis tersebut melandasi sikap para ulama pada waktu itu. ${ }^{4}$

Itulah beberapa faktor yang menyebabkan mengapa kaum muslimin Indonesia amat tercecer dalam segi intelektualitas ketimbang golongan lain. Akan tetapi keadaan berubah secara radikal setelah kemerdekaan Indonesia tercapai seakan-akan merupakan ganjaran untuk para pahlawan nasional sepanjang sejarah yang umumnya terdiri para ulama atau yang dijiwai oleh keislaman itu, kemerdekaan membuahkan sesuatu yang luar biasa manfaatnya bagi kaum muslimin, terutama dibidang pendidikan modern. Setelah itu bila membicarakan organisasi Islam dan kegiatannya dibidang pendidikan, sudah tentu tidak bias terlepas dari membicarakan bentuk system dan cita-cita bangsa Indonesia yang baru merdeka. Kemerdekaan Indonesia merupakan hasil perjuangan yang sekian lama terutama melalui berbagai organisasi pergerakan baik sosial, agama, maupun politik. Oleh karena itu wujud kemerdekaan adalah cerminan dari cita-cita perjuangan bersama dari bangsa Indonesia dan karenanya bentuk, system, dan tata cara pemerintahan disusun atas dasar cita-cita dan kehendak bangsa Indonesia tersebut.

${ }^{3}$ Timur Djaelani, Peningkatan Mutu Pendidikan dan Bangunan Perguruan Agama, (Jakarta: Dermaga, 1980), 135.

${ }^{4}$ Ridwan Saidi, Pemuda Islam Dalam Dinamika Politik Bangsa 1925-1984, (Jakarta: CV Rajawali, 1984), 6 
Dasar negara yang telah disepakati bersama saat mendirikan negara adalah pancasia yang tertuang dalam pembukaan undang-undang dasar 1945 dan merupakan kesatuan yang tidak terpisahkan dengan batang tubuh UUD 1945. Pancasila dan undang-undang dasar 1945 inilah yang kemudian dijadikan pangkal tolak pengelolaan negara dalam membangun bangsa Indonesia tersebut. Tujuan nasional bangsa Indonesia adalah seperti yang dirumuskan dalam dalam pembukaan undang-undang dasar 1945 yang berbunyi sebagai berikut: "Melindungi segenap bangsa dan seluruh tumpah darah Indonesia dan untuk memajukan kesejahteraan umum mencerdaskan kehidupan bangsa dan ikut melaksanakan ketertiban dunia yang berdasarkan kemerdekaan perdamaian abadi dan keadilan sosial". ${ }^{5}$ Sesuai dengan sila pertama dan pancasila yaitu ketuhanan yang maha Esa, dengan demikian berarti bahwa kehidupan beragama di Indonesia secara konstitusional dijamin keberadaannya seperti termaktub pada pasal 29 UUD 1945, yaitu: Pertama, Negara berdasarkan atas Ketuhanan Yang Maha Esa. Kedua, Negara menjamin kemerdekaan tiap-tiap penduduk untuk memeluk agamanya masing-masing dan untuk beribadah menurut agamanya dan kepercayaannya itu. ${ }^{6}$

Sebagai jaminan konstitusional ini membawa suatu konsekuensi bahwa pemerintah tidak hanya menjamin kebebasan tiap penduduk untuk memeluk agamanya masing-masing dan beribadah menurut agamanya dan keeprcayaannya itu yang secara konkrit telah disebutan pada pasal 29 tersebut melainkan juga sekaligus menjamin,melindungi, membina, mengembangkan, serta memberi bimbingan dan pengarahan agar kehidupan beragama dan bernegara berdasarkan pancasila. ${ }^{7}$ Pemerintah dalam usaha memenuhi amanat pasal 29 UUD 1945 tersebut selalu berusaha untuk memberikan kebebasan pada organisasi sosial, agama, dan politik untuk dapat berperan serta dalam pembangunan bangsa dan negara Indonesia yang merdeka. Karena itu dengan lahirnya berbagai organisasi cendekiawan seperti sekarang ini yaitu ICMI, IPKI, dan sebagainya senantiasa mendapat dukungan pemerintah. Pemerintah sadar sepenuhnya bahwa kekuatan negara terletak pada kesatuan dan

5 Endang Sudardja, UUD RI 1945 Dalam Hubungannya Dengan Pendidikan Moral Pancasila, (Bandung: Ghalia Indonesia, 1984), 83.

${ }^{6}$ Endang Sudardja, UUD RI 1945 Dalam Hubungannya Dengan Pendidikan Moral Pancasila, 89.

${ }^{7}$ Proyek Pembinaan Kerukunan Hiudp Beragama Depag RI, Pedoman Dasar Kerukunan Hidup Beragama, (Jakarta: 1983), 4. 
kesatuan berbagai organisasi dan golongan yang kesemuanya merupakan modal dasar dan kekayaan bangsa Indonesia yang harus dimanfaatkan sebesar-besarnya dalam pembangunan. Dengan demikian berarti bahwa pemerintah mengakui da menghargai betapa besarnya sumbangan dan peran organisasi sosial, agama, dan politik yang telah ikut serta dalam pembangunan bangsa.

Meskipun Indonesia baru memperoklamirkan kemerdekaannya dan telah mengalami refolusi fisik, pemerintah Indonesia sudah berbenah diri terutama memperhatikan masalah pendidikan yang dianggap cukup menentukan. Untuk itu dibentuklah Kementerian Pendidikan Pengajaran dan Kebudayaan (PP dan K). Dengan terbentuknya Kementerian Pendidikan tersebut maka diadakanlah berbagai usaha terutama mengubah system pendidikan dan menyesuaikannya dengan keadaan yang baru. Menteri pendidikan pengajaran dan kebudayaan (PP dan K) pertama KI Hajar Dewantara mengeluarkan intruksi umum yang isniya memerintahkan kepada semua kepala-kepala sekolah dan guru-guru yaitu:

1. Mengibarkan sang merah putih tiap-tiap hari di dalam sekolah.

2. Melagukan lagu kebangsaan Indonesia Raya.

3. Menghentikan pengibaran bendera Jepang dan menghapuskan nyanyian Kimi Gayo lagu kebangsaan Jepang.

4. Menghapuskan pelajaran bahasa Jepang serta segala upacara yang berasal dari pemerintah bala tentara Jepang.

5. Member semangat kebangsaan kepada semua murid-murid.

Seirama dengan perjalanan sejarah bangsa dan negara Indonesia sejak proklamasi kemerdekaan Indonesia pada tanggal 17 agustus 1945 hingga sekarang, maka sejarah kebijakan pendidikan di Indonesia termasuk di dalamnya pendidikan Islam memang tidak bias lepas dari kurung waktu tertentu, yang ditandai dengan pengingat. Oleh karena itulah perjalanan sejarah pendidikan Islam di Indonesia sejak Indonesia merdeka sampai tahun 1965 yang lebih dikenal dengan masa orde lama (ORLA), yang berbeda dengan tahun 1965 sampai sekarang yang lebih dikenal dengan orde baru (ORBA). Setelah proklamasi kemerdekaan Indonesia, sebagaimana dikemukakan terdahulu perubahan-perubahan diberbagai aspek juga dalam pendidikan. Perubahan yang terjadi dalam bidang pendidikan merupakan perubahan yang bersifat yang mendasar, yaitu dengan dasar dan cita-cita bangsa Indonesia yang merdeka. Untuk mengadakan penyesuaian cita-cita tersebut, maka bidang pendidikan 
mengalami perbahan terutama dalam landasan tujuan pendidikan, system persekolahan, dan kesempatan belajar yang diberikan kepada rakyat Indonesia. Tindakan pertama yang diambil oleh pemerintah Indonesia ialah menyesuaikan pendidikan dengan tuntutan dan aspirasi rakyat, sebagaimana tercantum dalam UUD 1945 pasal 31 yang berbunyi: Pertama, Tiap-tiap warga negara berhak mendapat pengajaran. Kedua, Pemerintah mengusahakan suatu system pengajaran nasional yang diatur dengan undang-undang. ${ }^{8}$ Oleh karena itu pembatasan pemberian pendidikan disebabkan perbedaan agama, sosial, ekonomi, dan golongan yang ada di masyarakat tidak dikenal lagi. Dengan demikian setiap anak Indonesia dapat memilih kemana dia akan belajar sesuai dengan kemampuan, bakat, dan minatnya. ${ }^{9}$

Pada periode orde lama ini, berbagai peristiwa dialami oleh bangsa Indonesia dalam dunia penddikan, yaitu:

1. Dari tahun 1945-1950 landasan pendidikan adalah UUD 1945 dan falsafah pancasila.

2. Pada permulaan tahun 1949 dengan terbentuknya negara Republik Indonesia Serikat (RIS), di negara bagian timur dianut suatu system pendidikan yang diwarisi dari zaman pemerintahan Belanda.

3. Pada tanggal 17 agustus 1950, dengan terbentuknya kembali negara kesatuan Republik Indonesia, ladasan idiil pendidikan UUDS RI.

4. Pada tahun 1959 presiden mendekritkan RI kembali ke UUD 1945 dan dan menetapkan manifesto politik RI menjadi haluan Negara. Dibidang pendidikan ditetapkan Sapta Usaha Tama dan Panca Wardhana.

5. Pada tahun 1965 sesudah peristiwa G 30 S/PKI kita kembali lagi melaksanakan pancasila dan UUD secara murni dan konsekuen. ${ }^{10}$

\section{Keberadaan Pendidikan Islam Masa ORLA}

Di tengah-tengah berkobarnya revolusi fisik, pemerintah RI tetap membina pendidikan agama. Pembinaan pendidikan agama tersebut

${ }^{8}$ Endang Sudardja, UUD RI 1945 Dalam Hubungannya Dengan Pendidikan Moral Pancasila, 89.

${ }^{9}$ Zahara Idris, Dasar-Dasar Kpenedidikan, (Bandung: Angkasa, 1981), 30.

${ }^{10}$ Zahara Idris, Dasar-Dasar Kpenedidikan ...,31. 
secara formal institusional dipercayakan kepada departemen Agama dan departemen Pendidikan dan Kebudayaan. Oleh karena itu dikeluarkan aturan-aturan bersama antara kedua departemen tersebut untuk mengelola pendidikan agama di sekolah-sekolah umum baik negeri maupun swasta. Khusus untuk mengelola pendidikan agama yang diberikan di sekolah-sekolah umum tersebut maka pada bulan desember 1946 dikeluarkan surat keputusan bersama (SKB) antara menteri pendidikan dan menteri agama yang mengatur pelaksanaan pendidikan agama pada sekolah-sekolah umum (negeri dan swasta) yang berada di bawah kementerian pendidikan. Maka sejak itulah terjadi semacam dualisme pendidikan di Indinesia yaitu pendidikan agama dan pendidikan umum. Disatu pihak kementerian agama mengelola semua jenis pendidikan agama baik di sekolah-sekolah agama maupun di sekolah-sekolah umum. Dan dilain pihak departemen pendidikan pengajaran dan kebudayaan mengelola pendidikan pada umumnya dan mendapatkan kepercayaan untuk melaksanakan system pendidikan nasional. Keadaan ini sempat dipertantangkan oleh pihak-pihak tertentu yang tidak senang dengan adanya pendidikan agama terutama golongan komunis, sehingga ada kesan seakan-seakan pendidikan agama khususnya Islam terpisah dari pendidikan.

Selanjutnya pendidikan agama ini diatur secara khusus di dalam undang-undang nomor 4 tahun 1950 pada bab XII pasal 20 yaitu:

1. Dalam sekolah-sekolah negeri diadakan pelajaran agama, orang tua murid menetapkan apakah anaknya mengikuti pelajaran tersebut.

2. Cara penyelenggaraan pengajaran agama di sekolah-sekolah negeri diatur dalam peraturan yang ditetapkan oleh menteri pendidikan pengajaran dan kebudayaan bersama-sama dengan menteri agama.

Sementara itu peraturan bersama menteri pendidikan dan menteri agama nomor 1432 tanggal 20 januari 1951 diatur tentang peraturan pendidikan agama di sekolah-sekolah yaitu:

- Pasal 1. Tiap-tiap sekolah rendah dan sekolah lanjutan diberi pendidikan agama

- Pasal 2. Huruf a. di sekolah-sekolah rendah pendidikan agama dimulai pada kelas 4 banyaknya 2 jam 1 minggu. Huruf b. di lingkungan yang istimewa, pendidikan agama dapat dimulai pada kelas 1 dan jamnya dapat ditambah menurut kebutuhan. Tetapi 
tidak melebihi 4 jam seminggu, dengan ketentuan bahwa mutu pengetahuan umum bagi sekolah-sekolah rendah itu tidak boleh dikurangi dibandingkan dengan sekolah-sekolah rendah dilainlain lingkungan.

- Pasal 3. Di seklah-sekolah lanjutan tingkatan pertama dan tingkatan atas baik sekolah-sekolah umum maupun sekolahsekolah kejuruan diberikan pendidikan agama 2 jam dalam tiaptiap minggu.

- Pasal 4. Huruf a. Pendidikan agama diberikan menurut agama masing-masing. Huruf b.Pendidikan agama baru diberikan pada sesuatu kelas yang mempunyai murid sekurang-kurangnya 10 orang yang menganut suatu macam agama. Huruf c. Murid dalam suatu kelas yang memeluk agama lain daripada agama yang sedang diajarkan pada suatu waktu, boleh mneinggalkan kelasnya selama pelajaran itu.

Dibidang kurikulum pendidikan agama diusahakan penyempurnaan-penyempurnaan dalam hal ini dibentuk suatu kepanitiaan yang dipimpin oleh K.H Imam Zarkasyi dari pondok pesantren Ponorogo. Kurikulum tersebut disahkan oleh menteri Agama pada tahun 1952. Pada ketatanegaraan Republik Indonesia dinyatakan bahwa negara berdasarkan UUD 1945. Kedaulatan ditangan rakyat yaitu ditangan MPR. Sebelum dibentuknya MPR menurut UUD 1945 di Indonesia pernah dibentuk MPRS pada tahun 1959. Selanjutnya, Pada bulan desember 1960 saat sidang pleno MPRS diputuskan sebagai berikut: Melaksanakan kegiatan dibidang mental/agama/kebudayaan dengan syarat spiritual dan material agar setiap warga negara dapat mengembangkan kepribadiannya dan kebangsaan Indonesia serta menolak pengaruh-pengaruh buruk budaya asing (Bab II Pasal 2 ayat 1). Dalam ayat 3 dari pasal tersebut dinyatakan bahwa pendidikan agama menjadi mata pelajaran di sekolah-sekolah umum mulai sekolah rendah (dasar) sampai universitas dengan perhatian bahwa murid berhak tidak ikut serta dalam pendidikan agama jika murid menyatakan keberatannya.

Pada akhir orde lama pada tahun 1965 lahir semacam kesadaran baru bagi umat Islam dimana timbulnya minat yang mendalam terhadap masalah-masalah pendidikan yang dimaksudkan untuk memperkuat Islam, sehingga sejumlah organisasi Islam dapat dimantapkan. Dalam hubungan ini kementerian agama telah mencanangkan rencana-rencana 
program pendidikan yang akan dilaksanakan dengan menunjukkan jenisjenis pendidikan serta pengajaran Islam sebagai berikut:

1. Pesantren Indonesia Klasik, semacam sekolah swasta keagamaan yang menyediakan asrama yang sejauh mungkin memberikan pendidikan yang bersifat pribadi, sebelumnya terbatas pada pengajaran keagamaan serta pelaksanaan ibadah. Baik guru maupun para muridnya merupakan suatu masyarakat yang hidup serta bekerjasama mengerjakan tanah milik pesantren agar dapat memenuhi kebutuhan sendiri.

2. Madrasah Diniyah, yaitu sekolah-sekolah yang memberikan pengajaran tambahan bagi murid-murid negeri yang berusia 7 samapi 20 tahun. Pelajaran berlangsung di dalam kelas kira-kira 10 jam seminggu diwaktu sore, pada sekolah dasar dan sekolah menengah 4 tahun pada sekolah dasar dan 3 tahun sampai 6 tahun pada sekolah menengah). Setelah menyelesikan pendidikan menengah negeri murid-murid ini dapat diterima pada pendidikan agama tingkat akademi.

3. Madrasah-madrasah swasta, yaiu pesantren yang dikelola secara modern yang bersamaan dengan pengajaran agama juga diberikan pelajaran umum. Biasanya tujuannya adalah menyediakan $60 \%-65 \%$ dari jadwal waktu untuk mata pelajaran umum, dan 35\%-40\% untuk mata pelajaran agama.

4. Madrasah ibtidaiyah negeri (MIN), yaitu sekolah dasar negeri 6 tahun dimana perbandingan umum kira-kira 1:2. Pendidikan selanjutnya dapat diikuti pada MTSN atau sekolah tambahan tahun ketujuh murid-murid dapat mengikuti pendidikan keterampilan misalnya pendidikan guru agama untuk sekolah dasar negeri setelahnya dapat diikuti latihan lanjutan 2 tahun untuk menyelesaikan kursus guru agama untuk sekolah menengah.

5. Suatu percobaan baru telah ditambahkan pada madrasah ibtidaiyah negeri (MIN) 6 tahun, dengan menambahkan kursus selama 2 tahun yang memberikan latihan keerampilan sederhana. MIN 8 tahun ini merupakan pendidikan lengkap bagi para murid yang biasanya akan kembali ke kampungnya masing-masing.

6. Pendidikan teologi tertinggi, pada tingkat universitas diberikan sejak tahun 1960 pada IAIN. IAIN ini dimulai pada dua bagian atau dua fakultas di Yogyakarta dan dua fakultas di Jakarta. 


\section{Penutup}

Setelah Indonesia merdeka terutama pada zaman orde lama, pendidikan Islam sudah mulai berkembang. Ini dibuktikan bahwa pemerintah pada saat itu sangat memperhatian pendidikan khsusnya dalam pendidikan Islam. Dengan berbagai usaha yang dilakukan pemerintah sehingga pendidikan Islam mulai berkembang walaupun di dalamnya ada berbagai macam kebijakan-kebijakan yang dibuat terkait dengan hal tersebut. Akan tetapi dari usaha yang dilakukan oleh pemerintah untuk mengembangkan pendidikan Islam maka para generasi dapat merasakan pada saat itu hingga zaman sekarang ini. Perkembangan Islam pada zaman orde lama juga mulai berkembang karena diadakannya dalam mata pelajaran baik tingkat sekolah dasar maupun pada tingkat untuk menengah untuk mempelajari pendidikan agama khususnya pendidikan agama Islam. Selain itu pula pada zaman orde lama ini mulai pula berkembang lembaga pendidikan Islam seperti pesantren dan beebrapa lembaga Islam lainnya seperti kampus di IAIN Yogyakarta dan Jakarta.

\section{DAFTAR PUSTAKA}

Djaelani Timur, Peningkatan Mutu Pendidikan dan Bangunan Perguruan Agama.Jakarta: Dermaga, 1980.

Idris Zahara, Dasar-Dasar Kpenedidikan, Bandung: Angkasa, 1981.

Langgulung Hasan. Pendidikan Islam dalam Abad Ke 21. Jakarta: PT. Al-Husna Zikra, 2001.

Saidi Ridwan, Pemuda Islam Dalam Dinamika Politik Bangsa 19251984, Jakarta: CV Rajawali, 1984.

Sudardja Endang, UUD RI 1945 Dalam Hubungannya Dengan Pendidikan Moral Pancasila, Bandung: Ghalia Indonesia, 1984.

Proyek Pembinaan Kerukunan Hiudp Beragama Depag RI, Pedoman Dasar Kerukunan Hidup Beragama, Jakarta: 1983.

Yunus Mahmud Sejarah Pendidikan Islam di Indonesia. Hidakarya Agung, 1985. 